10 years ESJ

Special edition

\title{
Trajectories of the deaf: a retrospective study based on the deaf and their family members
}

\author{
Ivani Rodrigues Silva, MA, PhD \\ Universidade Estadual de Campinas, Brazil \\ Kate Mamhy Oliveira Kumada, MA, PhD \\ Universidade Federal do ABC, Brazil \\ Zelia Zilda Lourenço de Camargo Bittencourt, MSc, PhD \\ Universidade Estadual de Campinas, Brazil
}

Doi: $10.19044 /$ esj.2021.v17n22p85

Submitted: 18 February 2021

Accepted: 12 April 2021

Published: 12 July 2021
Copyright 2021 Author(s)

Under Creative Commons BY-NC-ND

4.0 OPEN ACCESS

Cite As:

Silva, I. R.; Kumada, K. M. O.; Bittencourt, Z. Z. L. C. (2021). Trajectories of the deaf: a retrospective study based on the deaf and their family members. European Scientific Journal, ESJ, 17 (22) 85. https://doi.org/10.19044/esj.2021.v17n22p85

\begin{abstract}
The article aims to analyze the narrative of deaf and family members of an assistance service for the deaf people, identifying more striking perceptions in their life trajectories. The qualitative approach research was carried out through semi-structured interviews with three hearing mothers and three deaf children, former members of a university service for the deaf offered in the inland cities of the state of São Paulo, since the 1970's. The results showed that the aspects with the greatest impact for the participants return to the moment of diagnosis and forwarding to the referred specialized service; the challenges experienced in the school trajectory and the communication barriers still faced in the interaction with society.
\end{abstract}

Keywords: Family, Deaf education, Bilingualism, Narrative

\section{Brief history of education of the deaf in Brazil}

The education of the deaf in Brazil began in 1857 and for a long period was exclusively in charge of the National Institute of the Deaf (Instituto Nacional de Surdos - INES/RJ). As the only organ prepared to receive deaf 
people, INES housed students from all over Brazil and Latin American countries, in a boarding school regime and actively participated in the training of specialized teachers (Balieiro, 1989). In the city of São Paulo, it was only after 1933, by a private and religious initiative that educational assistance for the deaf began, becoming this the only option for almost two decades. An icon from that time is the Santa Terezinha Institute (Instituto Santa Terezinha), founded in April 1929, that still maintains a work of excellence aimed at this group of students. It was only around 1950 that the first initiative of the municipal education and the parents of deaf children started to emerge, which gave rise, respectively, to the Helen Keller Institute (Instituto Helen Keller) and the São Paulo Educational Institute (Instituto Educacional São Paulo) (today DERDIC, linked to PUC-SP). The state school system only manifested itself in 1957, with the creation of five special classes to assist deaf students, already inside regular schools. Both the institutes Santa Terezinha, the Helen Keller school and the São Paulo Educational Institute used an oral methodology that aimed at hearing and oral "training" in order to rehabilitate the speech of the deaf students, giving them greater chances to attend a regular school. It can be seen, therefore, that historically the education of the deaf has been based on a clinical view that saw the deaf from the perspective of rehabilitation and, for that reason, the special schools that were in charge of educating them have always been focused on the recovery of hearing residues and of oral language in order to "normalize it".

It is seen, thereby, that traditionally, the education of deaf people was under the responsibility of special education, marked by a clinical view in which "the deaf are narrated and described as disabled, with deficits, pathological cases, incomplete beings" (Favorito, 2006, p. 39).

Thus, it is possible to perceive that, for a long time, there has been an attempt to erase sign language to the detriment of the promotion of oral language and when confronting the history of deaf education, we see different moments, but which, in general, reflect an understanding of deafness as disability and incapacity. This posture resulted in the deaf person's invisibility in schools and even within their families, negatively impacting the educational process of this student.

\section{The deaf as a linguistic minority}

More recently it is still the complex situation experienced by the deaf in the school context (Góes \& Tartuci, 2002; Karnopp \& Pereira, 2004; Gesueli, 2003, 2004; Campos, Kober \& Melendez, 2004; Giordani, 2004; Silva, 2003, 2005; Fernandes, 2007; Cavalcanti \& Silva, 2007; Freire \& Favorito, 2007) and partly reflects the professionals' lack of knowledge about deafness and its singularities, showing the need and urgency for the discussion 
of different linguistic policies for this group of students. Questions regarding the educational situation of the deaf begin with studies that sought to unmask the devastating effects of oralism in the academic, social and affective life of the deaf people (Skliar, 1998). These studies, therefore, bring to the area a concept that until then was more associated with prestigious languages, such as English or French: bilingual education. After a few decades, these issues begin to be incorporated into the Brazilian universe and the school failure of the deaf people. From that moment on, it begins to be seen from another place, no longer as something inherent to deafness, but as an issue that affects minorities in general, whose mother tongue does not coincide with the one of the school system (Silva, 2005).

When we admit the deaf as bilingual individuals, we make their culture, identity and language visible, valuing and legitimizing their linguistic difference and distancing ourselves from that pathological view, within which this individual has been linked for a long time. In doing so, we are also integrating them into the position of linguistic minority, together with indigenous groups, immigrants, among other minority contexts (Cavalcanti, 2011).

According to Hamel (2003) "the right to language is part of fundamental human rights, such as the right to freedom of conscience, religion, belief or opinion, since these are considered natural attributes of every individual" (p. 58). And, as the author reminds us, "the State does not create these rights, it only recognizes them" (p. 58), if there is such a desire in society. It is known that in the context of deafness, this recognition of linguistic rights was denied to deaf people for a long time, and communication through oral languages was imposed on them. Only very recently have they been considered as part of minority groups and their language has been raised to the category of natural languages, and is no longer seen as "mimicry" or other pejorative adjectives as it was previously called.

The lack of knowledge about what deafness means is one of the difficulties for the implementation of programs that integrate the needs of the deaf student. Society, in general, does not know how these students learn to read and write, how they interact with the world through a visuospatial language, how they constitute themselves as individuals. Authors such as Quadros and Karnopp (2004) even describe some myths that still prevail in relation to the deaf and deafness, and that hamper substantive changes in the school life of the deaf individual. They are:

1 - Sign language would be a mixture of pantomime and concrete gesticulation, unable to express abstract concepts;

2 - There would be a single and universal sign language used by all deaf people; 
3 - There would be a flaw in the grammar organization of sign language that would be derived from sign languages, being a pidgin without its own structure, subordinate and inferior to oral languages;

4 - Sign language would be a superficial communication system, with restricted content, being aesthetic, expressive and linguistically inferior to the oral communication system;

5 - Sign languages would derive from the spontaneous gestural communication of hearing individuals;

6 - Sign languages, as they are spatially organized, would be represented in the right hemisphere of the brain, since this hemisphere is responsible for the processing of spatial information, while the left hemisphere is responsible for the language. (Quadros \& Karnopp, 2004, pp. 31-37)

It is perceived that it is not a simple thing for people to value the language of the deaf community as a natural language. In this way, it is understood the importance of education in the surroundings (Maher, 2007), under punishment for this group not having their language recognized and the processes of identification and exclusion to which they were subjected for centuries, equally, not being reflected and denaturalized, by the majority society. This difficulty of understanding in relation to all these issues explains the place still reserved for the deaf in our society and the stereotypes in relation to this group of people, as well as the interdition of sign language in the school space, factors that contributed in the past and still contribute, negatively, for the education of the deaf. Maher's argument (2007) is that it is not enough for minorities themselves to be aware of their rights for the "scenario of linguisticcultural oppression in which they live to be, in practice, modified" (p. 257). It takes more than that!

When pondering the necessary care when planning educational programs aimed at linguistic minorities Maher (2007) emphasizes that we cannot fail to privilege three important aspects, namely: the empowerment of these groups, the favorable legislation and the education of the surroundings, since, according to the author "the empowerment of these groups depends not only on their political strengthening or on the existence of legislation that is favorable to them, but also on the education of their surroundings to guarantee this respect" (p. 255).

To better understand this experience lived by the deaf in the spaces previously reserved for the hearing, Skliar and Quadros (2000) propose an epistemological inversion, that is, they request that a situation be imagined in which the hearing could be in the position of the deaf, within a education 
system in which was not allowed to speak Portuguese and within which the Portuguese language, the language of the hearing students, was not part of school books and, also, was the instruction language of the school. With this reflection, the authors problematize the current situation in which the deaf find themselves and highlight the absence of the Brazilian Sign Language (Libras) in this space, their stereotypes towards the hearing people; the experiences of children of hearing parents and deaf parents; the visual culture of the deaf people; among other experiences in the deaf world that are not valued or that are unknown to the hearing society.

Within this more current perspective, the early insertion of the deaf child is encouraged in conversations using the sign language with deaf peers and / or deaf adults and, in addition, it is claimed that oral or written Portuguese is taught to them within the precepts of the second language. For this reason, also, the Bilingual Education area in deafness is concerned with the learning of Libras by family members and most programs that work in a bilingual approach for deaf people favor the family's contact with this language (Lopes, 2006; Silva, Kauchakje \& Gesueli, 2003; Giroto, Toppan Junior, Martins \& Veri, 2005; Goldfeld, 2006). However, as previously mentioned, this is a recent model of education for the deaf, whose transition process involving oralism and bilingualism has left its mark on deaf individuals and their families.

Given the above, the objective of the research is to investigate the deaf and family members' narrative about their experience in an assistance service for the deaf people, identifying their most striking perceptions in their trajectories.

\section{Materials and methods}

Using ethnographic research (Erickson, 1989) aligned to a qualitative approach (Severino, 2007), semi-structured interviews about family and linguistic experiences were conducted with former members of a program for the deaf offered in Campinas, an inland city in the state of São Paulo ${ }^{1}$.

The selection of participants included a retrospective survey of the medical records of users assisted since 1973 at the Center of Studies and Research in Rehabilitation "Prof. Dr. Gabriel O. S. Porto" (Centro de Estudos e Pesquisas em Reabilitação), located in the Faculty of Medical Sciences (Faculdade de Ciências Médicas) of Campinas State University (Universidade Estadual de Campinas) (Cepre/FCM/Unicamp).

${ }^{1}$ This project was submitted to the Research Ethics Committee in the Faculty of Medical Sciences of the State University of Campinas and approved under the statement no. 437/2006 and CAAE: 0343.0.146.000-06. 
This Center was inaugurated in 1973 and works until the present day, developing an interdisciplinary work ${ }^{2}$ in the area of sensory disabilities. Regarding to deafness, its goal is to support deaf children, adolescents and adults, aiming at their insertion in the larger community. It offers programs for different age groups ${ }^{3}$, whose objectives are to work with reading and writing as social practices, contact with Libras through deaf adult teachers who are proficient in sign language, assessment and prevention of disabilities and its development in deaf children and deaf adolescents, intervention on issues related to inclusion, special education, family, public policies and citizenship. It also offers adaptation of hearing aids, speech therapy for oralization and orofacial reading, advisory and supervision for teachers of regular and special education in the city of Campinas and vicinities.

The choice of the research context was in line with Erickson's prerogative (1989), involving the possibility of approaching spaces whose researcher's view became familiar, in order to strange it, problematizing "Why are you this way and not another way?" (p. 200) and with that, makes it interesting again.

Thus, through the survey of users assisted by Cepre, it was possible to establish the selection of individuals through "sampling by variety of types" (Turato, 2013), choosing as inclusion criteria: being deaf and having been a Cepre user; have continued their studies or entered the job market; agree to participate in the study and sign the consent form ${ }^{4}$. Thereby, six participants were selected, three hearing mothers and their respective deaf children, as shown in Tables 1 and 2:

\footnotetext{
${ }^{2}$ Cepre is characterized as a center that brings together several professionals from different areas of activity, such as speech therapy, pedagogy, linguistics, psychology and social work. ${ }^{3}$ In the assistance area of the deafness field, the programs support different age groups: Programa infantil de atendimento à criança e família (Assistance Program to children and families) that receive deaf children aged zero to three years old; Programa Linguagem e surdez (Language and Deafness Program), which assists deaf children aged four to seven; Programa escolaridade e Surdez (Schooling and Deafness Program) that assists children from seven years onward.

${ }^{4}$ The approach of the deaf participants was favored, as they were in professional activities and / or training and research in Cepre.
} 

LANGUAGE AND EDUCATION: THINKING (AND DOING) OTHERWISE

\begin{tabular}{|c|c|c|c|c|c|}
\hline Name & $\begin{array}{c}\text { Year of } \\
\text { ingress } \\
\text { in Cepre }\end{array}$ & $\begin{array}{c}\text { Deaf person's } \\
\text { age at the } \\
\text { ingress (egress) } \\
\text { in Cepre }\end{array}$ & $\begin{array}{c}\text { Education level } \\
\text { at the time of } \\
\text { the interview }\end{array}$ & $\begin{array}{c}\text { Profession at } \\
\text { the time of } \\
\text { the interview }\end{array}$ & $\begin{array}{c}\text { Marital } \\
\text { status }\end{array}$ \\
\hline João & 1989 & $\begin{array}{c}\text { 1 year old }(10 \\
\text { years old) }\end{array}$ & $\begin{array}{c}\text { Studying higher } \\
\text { education }\end{array}$ & Student & Single \\
\hline Mariana & 1976 & $\left.\begin{array}{c}5 \text { years old }(10 \\
\text { years old }\end{array}\right)$ & High school & $\begin{array}{c}\text { Libras } \\
\text { instructor }\end{array}$ & Married \\
\hline Fernanda & 1988 & $\left.\begin{array}{c}\text { 1 year old }(8 \\
\text { years old }\end{array}\right)$ & High school & $\begin{array}{c}\text { Production } \\
\text { assistant }\end{array}$ & Married \\
\hline
\end{tabular}

Table 1: Characteristics of deaf participants of the research

\begin{tabular}{|c|c|c|c|}
\hline Name & Characteristic & Profession & $\begin{array}{c}\text { Year of ingress } \\
\text { in Cepre }\end{array}$ \\
\hline Ruth & Hearing mother of João & Housewife $^{7}$ & 1989 \\
\hline Carmen & $\begin{array}{c}\text { Hearing mother of two deaf } \\
\text { children (Fábio and Mariana) }\end{array}$ & Housewife & 1976 \\
\hline Cristina & Hearing mother & General services & 1988 \\
\hline
\end{tabular}

Table 2: Characteristics of family members participating in the research

The contact with the deaf individuals took place through Libras, with the interviews filmed, with consent and, later, transcribed. In parallel, the relatives of these individuals were contacted for an interview also recorded on audio and video, whose transcribed data were organized for its analysis. It should be noted that the records were analyzed using the method of analytical induction proposed by Erickson (1989), based on exhaustive (re)readings of the corpus, in search of evidence to build answers to the research objective. In view of this procedure, it was possible to identify three aspects of greatest impact for the participants, namely: the moment of diagnosis and forwarding to the specialized service offered by Cepre; the challenges handled in the school trajectory and the communicational barriers faced in the interaction with society. These topics are covered in the following results.

\section{Diagnosis and referral to Cepre's assistance service}

In the context of deafness, according to Françoso (2003), one cannot lose sight of the fact that, often, hearing parents work with the grief of an ideal child, triggered from the moment of the child's hearing loss diagnosis. For this

\footnotetext{
${ }^{5}$ This participant returned to Cepre as a Libras instructor in adulthood, as well as other deaf former students of the program.

${ }^{6}$ It should be noted that the referred participant returned to the program at the age of 14 and remained until the age of 16 , when she was in high school.

${ }^{7}$ During her stay in the program, Ruth felt the need for further training and sought the Pedagogy course with a qualification in the hearing impairment area.
} 
author, dealing with the news of deafness can really be compared to the death of someone and, therefore, there are feelings that are boiling, such as denial, anger, vulnerability, guilt, depression, confusion and acceptance, without these being placed in a linear way can be relived throughout life. In this sense, the unpreparedness of some professionals in the medical field, responsible for assessing deafness and who approach family members, is noteworthy. In the reports of Ruth and Carmen, it is possible to follow this testimony:

Ruth (João's mother): It was a shock, because even though I knew that, like, I was almost certain that he was deaf, I had a hope that he was not and my husband had $100 \%$ hope [...] and the doctor broke the news very coldly, you know? He didn't prepare us, he came in, did the exam, everything and came back. He sat at the table and said: "the boy is deaf". So, already gave the address of Gabriel Porto [Cepre] to us. Then we left the building, I remember that my husband turned the corner, looked up and cried. Wow, it was sad, I still remember it until today, and he looked up, a tear flowed and he said: "I never want to pass by this building again". You see what the doctor's lack of psychology is.

Carmen (Mariana's mother): Then when Mariana was born I decided to look for an otolaryngologist. Then I took her and the doctor certified [that she was deaf]. My God, that day the roof fell on my head. Then I cried, cried, cried everything I had to cry. Then I stopped, because I have a degree, I am a teacher. [...] Because I have to look for something for them, try to give them education.

Ruth asserts that there was a lack of sensitivity and information by the doctor when communicating to her and her husband the deafness of their son, causing a lot of suffering for the couple at that time. It is observed that despite the gap of a decade between the two diagnoses received by the mothers, the same perception can be glimpsed in the statements when they describe the crying and discomfort of that moment. It is relevant to point out that Carmen is the mother of two deaf children. Although Fábio is the eldest son, in Mariana's diagnosis, the other youngest deaf daughter, his diagnosis would come earlier because his hearing loss was greater. In both cases, Cepre was mentioned by the mothers as the place where families could be welcomed with the greatest attention.

Carmen (Mariana's mother): When I saw those fourteen, fifteen years old girls walking alone, you know? At Campos Sales, at Treze de Maio, I said "Wow, [...] will my children ever make it?" We keep thinking $[\ldots]$ so they were able to stand on their own feet. So, mothers 
give us strength, because we, at that meeting of mothers, we see, you know? Each problem of each one." "Because when I put her there at [Cepre] Gabriel Porto, then I felt more relieved because I saw that it wasn't just me, there were several mothers going through the same I was going through. This is a relief for us, then I saw it, I had the support.

Carmen recalls that the assistance provided by Cepre was not restricted to the reception of deaf children, being extended to family members assisted in a group by a professional in the psychology field. In fact, other assistance programs for deaf people understand that family support must be provided, given the importance of the interactions established in the child's first years of life (Giroto et al., 2005; Goldfeld, 2006). For A. B. P. Silva (2003) the quality of the family-child interaction will be crucial to the formation of the deaf individual's self-image, and "this affective adaptation will depend on how the family reacts to the diagnosis of deafness and manages to develop the grief of the perfect child, modifying all their expectations in relation to him" (p. 93).

It is worth noting that when asked about the moment of the diagnosis of her daughter's deafness, Cristina, Fernanda's mother claimed that she did not experience any difficulty, because as reported, she previously had contact with deaf people and was interested in learning the sign language, taking a more positive view of the situation. For Cristina, the most difficult thing was getting along with people who did not accept her daughter. Possibly, in addition to previous contact with deafness, it is believed that this more positive way of facing hearing loss was influenced by a less traumatic medical approach at the time of diagnosis. Even so, other challenges are present in the narratives of deaf and family members and, frequently, go back to the school period, as discussed below.

\section{The school trajectory of deaf students}

Under the retrospective of the school trajectory, the narrative of deaf people and their hearing family members pointed out as challenges from resistance in enrollment, crossing the difficulty of learning and communication at school to the lack of help that demanded greater support from the family outside the classroom.

It is stated in the article 26 of Universal Declaration of Human Rights (United Nations, 1948) that "everyone has the right to education", being instituted in the national legal system, through Law 7.853, as a crime punishable by imprisonment for two to five years and a fine for those who "refuse, charge additional values, suspend, procrastinate, cancel or stop student enrollment in a public or private educational institution of any course 
or degree, due to their disability" (Law n. 7.853, 1989). It is also complemented by the aforementioned law that the penalty can be aggravated by one third when the referred crime is committed against persons with disabilities under the age of 18 . Despite this, the barriers faced by family members to ensure access and permanence of their deaf children in school are striking:

Carmen (Mariana's mother): I searched a lot [...] because at that time, not now, now schools are accepting more. But I suffered a lot, I found doors closed, you know? But I went ahead, I went ahead. Then I said: you know what? I have to look for a specialized school. [...] [one day] The principal called me there, said to me: look, I never had a disabled student here, I don't have a specialized teacher, I don't know how it is, I don't know if they will get along here [...] I said: look, they did very well from the fifth to the eighth grade [...] now if I brought them here it is because I know they have the capacity, otherwise, I would not bring them, take a child and put him over there, you know? Will I push him there? I said: no, that's not it. Then he said that he never had a deaf student, that I think they would return even the enrollment fee, the first tuition I had paid, whatever. [...] so I told him to stay with them for a few days [...] do an evaluation with them [...] and then, if you think they are not able to stay there [...]

Cristina (Fernanda's mother): [the school principal said to my daughter] "today is your last day here, you don't study here anymore, because you are deaf and here is not your place". She [the deaf daughter] started crying, she cried the whole class. She got home, she couldn't speak. [...] Then I went to talk to the principal "no, Fernanda doesn't study here anymore, it's over. Fernanda has to go to the deaf school". Then I went to the Schooling Delegacy.

In Carmen's testimony, it is observed that she was consulted by the principal of the specialized school for the deaf to refer her children to a regular school, since she believed that they could have their performance improved in this space. However, she reports that she had to insist to convince the private school to accept her children, emphasizing that they were able to be there. It is observed that Carmen's argument does not fall on the field of law, but on the merit of her children being there. In addition, according to Carmen, the refusal was also recurrent in non-formal education spaces, such as in computer courses that justified that Fábio could not enroll because he was "disabled."

In turn, Cristina is more empowered and when she received the news that her daughter's enrollment would be terminated, she turned to the higher court to guarantee her rights. However, it is a fact that Carmen faced these 
challenges in the 1980s, while Cristina's testimony refers to the 1990s, a period in which the inclusion paradigm (which defends that it is the school that must adapt to the diversity of its students) begins to be propagated, differentiating itself from the integration paradigm, where the student is the one who should adapt to the school (Mendes, 2006). Thus, different periods mark the family members' narratives and shape their discourses on the education of the deaf, showing few changes. This reinforces the position of Maher (2007) in face of the importance of the triad composed by favorable legislation, empowerment of the individuals and education of the surroundings.

And, even though the 1990s started the inclusion paradigm (Mendes, 2006), all participants described the lack of school support and the need for family members to take responsibility for the study of their children in the extra-class period.

Carmen (Mariana's mother): [Mariana] afterwards there was the reinforcement in Cambuí with Beatriz, she taught reinforcement classes, it was very good for her. I reinforcing at home... Now, the subject she had difficulty with was reading the books, the books she had a literary class, everything, right? And do the summing-up. But I read all the books, I went to the library [...] to do their assignments, look up, research everything $[\ldots]$

Ruth (João's mother): I don't like [...] I don't want to speak ill of it, I can't bite the hand that fed me, because the school was very good and I am very grateful because they received him. But, like, there was no, no special attention. He had to run after it, otherwise... then there was this subject that he tried to read the teacher's lip at most, if he didn't get it, he lost it. Then at home I checked the lesson with him, resumed that day's lesson and advanced the next day's [...]. It was not easy, saying that it was easy, it was not. It's really hard, you have to give up a lot, we have to give up a lot of things in our lives. [...]

In line with Almeida, Ferrarotto and Malavasi (2017), the recognition of the importance of the family role in the schooling of children has been increasingly frequent in their participation in researches that cover the school trajectory and the students performance. This is because it is recognized that, although much is said about the lack of parental participation in the education of children, there are family members engaged in this endeavor. 
With regard to the education of the deaf, it is noted that this is reinforced. Carmen states that the school period was the most difficult, as the children did not follow the classes, requiring the daughter to attend "school reinforcement" and the mother to monitor her education more closely to make up for the gap left by the teachers. Ruth also says that due to the lack of a pedagogical project for the deaf student by the school, she had to give up a lot of things, devoting more attention to her son's lessons, resuming what was taught in class and advancing the following classes. Evidently, it is understood that the family must participate in the education of the children, however, the reports presented here describe an excess dedication to the deaf children, since the permanence of these children in school depended on this posture, that is, the maintenance of winning their place in a regular education, which at the time was highly valued by the interviewed family members.

Currently, Ruth's son is proud to say that he was approved at two renowned private universities, but he also keeps memories of the difficulties in his educational process. For example, when the Libras interpreter went only once a week and, although he did a good lip reading, the teacher's poor positioning in the classroom, who spoke with her back to him, made the use of this resource unfeasible. This was also a complaint present in the statements of Fernanda and Mariana:

Fernanda: The teacher fought a lot $[. .$.$] there are some teachers who$ ask and forget, speak with their back to us. And I am facing them and they forget to speak in front of me and I do not know what they are saying [...] then I have to say "Hey, teacher" and then repeat. Then it's tiring.

Mariana: [at school] it was difficult, because the teachers did not know sign language, wrote on the blackboard and spoke. And I copied from a friend. [...] The teacher spoke, I understood a little and wrote, but it was difficult because the teacher only spoke [orally].

Fernanda and João also recall that the special education offered to deaf students at the time had the habit of retaining them for two years in each grade, regardless of their potential or performance.

João: the study was weak and time-consuming. It took two years in each series, I was going to get old.

Fernanda: Only at [name of the institution] I was retained [because there are two years for each grade] and because my age was different from the others, the others were older than me. 
Cristina (Fernanda's mother): And there she had a serious problem, because since she left here [from Cepre] practically literate, when she left here she already had a lot of knowledge with words, you know? We also worked at home. When she got there [...] the class was still in the Eeeeii Biiiiii (laughing). So, when it came to, like, sentences, it was much easier. So, what happened? She was taken out of the classroom to help other teachers in other classrooms. [...] she was not advanced, like [...] when she was in the second grade, she always went to the first grade to help in the first grade, either the teacher, or the principal, or a friend.

Based on the excerpts, it is noted that João chose to study at a private regular school, as he felt that he would be left behind if he remained in the school for the deaf. Similarly, Fernanda and her mother say that the school assigned the student the task of assisting the teacher or the principal, without considering the possibility of advancing her year, since they required her to accompany her colleagues of the same age, even if they were behind time.

It should be noted that, remembering this period of schooling, Mariana and Carmen were cautious in considering that even at Cepre, when initially supported by an oralist approach, they were not successful in the process of learning the oral or written language.

Mariana: I was attending a speech therapy, but I didn't learn to speak, because there were words, but what do they mean? The teacher showed things and asked the names. I forgot the words, because it was oralism. [...] Here [at Cepre] I glued the names on things, at my house too. Then I went to the special school and saw the deaf talking in Libras and I learned. When I learned sign language, it became easier to learn words. There, I developed the signs first, then the words.

Carmen (Mariana's mother): I thought, I complained, I thought it was like that, right? That she couldn't make signs. [...] that is, it was still little [the sign language was widespread]. Ah, in the association, now I remember, in the association, this is where they [the children] joined the association, then started that fever of [sign language], that's when it started.

Although Carmen never learned Libras, she admits that she criticized the institution's stance in not allowing the use of signs with deaf children and their introduction in Libras was essential for their development. Mariana, who in her adult years came to act as a Libras teacher at Cepre, also recalls that 
period of exclusively oralist approach of the referred institution, in which the language was approached without much sense for her. According to her testimony, it was from the contact with the first signs that words started to have meaning in her life.

Since the 1980s, Cepre has aligned itself with a bilingual approach, with this transition period accompanied by some of the participants in these surveys, such as João and Fernanda, as well as by their family members who learned Libras and started using it with their children. At that institution, like Mariana and João, other deaf former students have already come back to the program as adults or as teachers or participants in research groups and projects. In addition, it is noteworthy that many of the deaf assisted in these nearly five decades of Cepre's history accessed higher education and some are in teaching institutions, working in both basic and higher education. However, even with changes in society due to the diffusion of knowledge about the deaf, deafness and sign language, communicational barriers are often reported.

\section{Communication barriers faced in interaction with society}

Considering that most deaf children are born in hearing families that, in general, have little or no contact with deafness (Sacks, 1998), we understand the complexity of their communicative relationships from an early age. Thus, according to studies carried out (Tervoort, 1961; Silva, 2005; Kumada, 2012; Vilhalva, 2009), it is common to identify the establishment of alternatives for communication between hearing family members and their deaf children that go beyond the binarism of the Portuguese language and the sign language, establishing an interstitial space that, borrowing the concept of Bhabha (2007) can be conceived as a third space, constituted of hybridism, but also of the new, of "neither one nor the other". It is what some authors have called "esoteric symbolism" (Tervoort, 1961), "emerging sign language" (Vilhalva, 2009) or "home sign languages" (Silva, 2005; Kumada, 2012).

According to Kumada (2012), people popularly refer to this communication as "gestures", "home signs", "mimics" or "invented signs", thus seeking to delegitimize any linguistic traits present there. For the author, although it presents a restricted understanding to her interlocutors, the family members interviewed in her research admitted a high degree of functionality to home sign languages. So also the communication of deaf people and their hearing family members was marked in reports such as that of João and Ruth:

Ruth (João's mother): The father [of my deaf son] doesn't know Libras, he makes the wrong signs, but he communicates.

João: We [my mother and I] got used to talking [orally], then we understood and, sometimes, we invented signs. 
Although João is considered an oralized deaf as his main form of communication is through the Portuguese language (oral and written), he used a Libras interpreter in his school and university trajectory and his mother also felt the need to get in touch with sign language. Even so, they comment that the habit of "inventing signs" and of moving between Libras and the oral language was common. Likewise, João's father demonstrates that he has managed to communicate with his son, even using what the mother expresses as "wrong signs".

The need to use different resources is also present in other spaces for social interaction, as João reports that his orality is not always understood:

João: For example, in the store. To shop, I talk to the salesperson, but she doesn't understand, I need to take a paper and write. [...] Whenever I go to eat at the mall, coke or guarana, I always drink coke, because I have difficulty speaking guarana. [...] At Mc [Donalds] I always ask for the number, eight or four, because by the name she doesn't understand.

Similar situations are described by Mariana, whose main communication is Libras:

Mariana: At the doctor is difficult, dentist too. You need an interpreter. I have never been alone, but I have already been with my husband, because my husband hears a little, or my son goes and he interprets. Not at the supermarket, because you don't need to talk to anyone. I choose things and pay for them. In stores, people understand me because I point. At the bank is also difficult, an interpreter is needed.

Thus, it can be noticed that the lack of understanding of João's speech and the need of a Libras interpreter assistance to Mariana, compromise communication and, therefore, their degree of autonomy in society, which denotes that regardless of linguistic choices, deaf participants of this research record the confrontation of barriers in social interaction.

For Mariana, mother of two hearing children, the school remains excluding and without professionals who are prepared to deal with deaf family members. Back to school, in her adult life, Mariana reports the anguish of the episode in which she needed to talk to her son's teacher:

Mariana: my son was sick with bronchitis and I was alone. I needed to go to school to tell her that he was sick. The teacher speaks, speaks fast and I don't understand. I sat in front of the teacher and said I 
didn't understand. Then I started to get nervous. I saw some tests, I tried to explain and the teacher did not understand. Then I took a paper and wrote it. Then the teacher understood. I went to complain to the principal.

As pointed out above, writing frequently becomes the solution for deaf individuals, just like recorded by Fernanda:

Fernanda: Sometimes, when they don't understand what I'm talking about, then I say "wait a little bit", then I go and get a paper to see if they understand. Also other friends always write for me.

According to Cavalcanti and Silva (2007), we live in a graphocentric society in which it is undeniable the demand for the domain of writing under the pretext of professional success. However, in the context of deaf education, this is often reinforced by the school as a survival strategy, as according to representations of teachers interviewed by the author "If he [the deaf] does not speak Portuguese, he has to be with paper and a pen, because the pen is his voice, right?" (Cavalcanti \& Silva, 2007, p. 229).

Thus, for Cavalcanti and Silva (2007), under the lens of relatives and teachers, the writing of the deaf is valued as a compensation for the absence of an oral language and, as can be seen in the reports of our participants, such conceptions influence these deaf as adults, assigning responsibility for the deaf-hearing interaction exclusively to the deaf. As a result, although the integration paradigm has been theoretically replaced by an inclusive perspective, the deaf person still has the task of adapting to the hearing society to access the most different spaces, as well as to be accepted and tolerated.

For Skutnabb-Kangas (1981), when it comes to minority bilingualism, students are subjected to social pressure from families and the school to improve their mastery in the second language, being registered as their only chance to rise in the educational and economic areas.

In the trail of this logic,

If the children become monolingual or very proficient in their own language, then most future educational opportunities will close for them. They will not be able to compete in the job market with other young people in the majority community. Their chances of participation in the life of the majority community and their influence in it will be severely limited. With this, it will also be impossible for them to try to improve the situation of their own group, together with others, due to linguistic demands and other rights for their group. (Skutnabb-Kangas, 1981, p. 79) 
Thus, years of oralist hegemony that brought negative implications for the school learning of the deaf people were justified, as well as traumas to those who were educated in this approach. According to Gesser (2009), deaf adults who were subjected to the oralization process in their childhood, currently bring in their report a great discomfort when learning the Portuguese language, demonstrating, even, a certain "prejudice against those who want or like oralization" (p. 51).

Thus, if, on the one hand, deaf people who communicate through Libras may suffer discrimination from hearing people, who find their way of communication strange, on the other hand, oralized deaf people also report facing prejudice among bilingual deaf people.

João: I went to the mall with my friends and then a strong deaf man came to the table, when he saw me, I didn't know him, he asked who I was. He said: "Are you a hearing, are you a hearing?" I said, "No, I'm deaf". He looked at me differently. I feel part of the hearing people, because I hang out with the hearing group and I don't use Libras, I just speak [orally].

João: [I'm not ashamed of Libras] but, I don't like it because people keep looking. [...] At the mall, with deaf friends making Libras, people pass by and keep looking.

Mariana: The hearing people left me aside.

Mariana says that hearing students segregated her due to her way of communication. João describes that he also felt embarrassed both in the company of the deaf and hearing. This happens because when he is among the deaf he perceives the eyes of the hearing people focused on their communication in Libras

In fact, it is noted that the deaf being brings, regardless of their linguistic choice, a degree of prejudice that impacts the deaf and also their family members. In this regard, Carmen recalls how she was bothered when neighbors reported to her two deaf children and, similarly, Cristina points out the importance of family members in supporting the deaf individual:

Carmen (Mariana's mother): Before there was, when they were small, there was a lot of prejudice. Too much! [...] The neighbors said to me: "poor thing!" I used to say: "No way! Why poor thing? [...] They just have a small hearing impairment." 
Cristina (Fernanda's mother): [...] We taught her, because when she was little she was ashamed to speak, ashamed to use signs, to use a device, everything that the deaf feel, because the deaf feel it, right? And we managed to get it out of her, to show her that she has value, she is deaf, but only deaf. Nothing more than deaf. She can win in life, she can grow.

It is admitted then that, the perspective of hearing family members is little figured in the literature involving the education of the deaf, in the sense of attributing a voice to them and triangulating their perceptions from the angle of the testimony of deaf children. It is believed that listening to these individuals can be useful to know narratives about challenges experienced and shared with the deaf and to improve policies that foster bilingual education in this context.

If technically bilingual education corresponds to that in which two languages are used as a means of instruction, according to Hornberger (2001), the model fostered in the vast majority of regular schools throughout Brazil cannot be called 'bilingual education', since the means of instruction by which the deaf child or adolescent will have access to knowledge is not under discussion, with written or oral Portuguese being mostly encouraged.

Freeman (1998) stands in favor of the model that provides additive or enrichment bilingualism for minority students and those belonging to the majority communities, as the goals of this program are linked to academic instruction - done through both languages - and cultural pluralism, that is, the demarcation of spaces for the two languages to appear within the school curriculum, integrating families and the larger society within this spirit of appreciation and respect for the languages and cultures that are in contact. All of this, according to the author, can provide academic competence in two languages for the two groups under discussion, fighting prejudice and discrimination with knowledge. This would be the ideal world for the context of deafness, but it is still far from happening in practice.

\section{Final considerations}

In this article, to to show the complexity of the context of deafness and schooling, we approach the narratives of deaf and family members involved in an assistance service for the deaf people, following their perceptions about the inclusion of deaf students in regular education, starting from basic education to the university, as something that, in fact, worries because this space is not yet prepared to receive students from minority groups who use another language (in the case of deafness, Libras) and still need to learn Portuguese (the school language) as a second language. 
We hope to have marked that the failure of deaf education is not directly related to the fact that they have not been oralized, but to the fact that their education is thought exclusively within a graphocentric orientation, specific of the school, and from the perspective of an oral language, proper to the hearing world.

We believe that the reflection presented shows that it is possible to understand the importance of raising awareness of the school in general, from basic education to higher education (administrators, teachers, employees, hearing students), the families of deaf students and hearing students, institutions that educate teachers (academic staff, students: undergraduate students) and institutions for research and for training trainers (graduate students, and teacher-trainers). From this awareness of the social, cultural and linguistic aspects of this complex context, the need and interest to learn Libras by teachers in service, teachers in training and family members of the deaf could arise (Cavalcanti \& Silva, 2007).

Our results showed that the diagnosis of deafness, experiences in the schooling process and communication difficulties are pointed out as the most striking perceptions that accompanied the narratives of deaf and family members interviewed. These narratives portray the failure in welcoming the medical field in the face of the news of hearing loss, the denials of access and permanence of the deaf in school spaces, the renunciation of mothers to other areas of their personal life for dedication to their deaf children's education, discrimination suffered by the deaf, regardless of their linguistic choice and the overvaluation of Portuguese writing as a communicative resource, with oral and sign language recognized as ineffective in interaction with hearing people.

The registered challenges are indicators of struggles that still need to be carried out through effective linguistic policies that recognize the particularity of the sociolinguistically complex context of these individuals. In other words, the aspects raised demand action by the public authorities and society, in the expectation that, in the not-so-distant future, deaf people and their families can share more positive narratives about their trajectories within society and school.

\section{References:}

1. Almeida, L. C., Ferrarotto, L., \& Malavasi, M. M. S. (2017). Escola vista de fora: o que dizem as famílias? Educação \& Realidade, 42(2), 649-671.

2. Balieiro, C. R. (1989). O deficiente auditivo e a escola: relatos de algumas experiências [Unpublished master's thesis]. Pontifícia Universidade Católica de São Paulo. 
3. Bhabha, H. K. (2007). O local da cultura (4th ed.). Editora UFMG.

4. Campos, S. R. L., Kober, D. C., \& Melendez, A. J. (2004). O recurso midiático como portador de texto no letramento de crianças surdas. In A. C. B. Lodi, K. M. P. Harrison \& S. R. L. Campos (Eds.), Leitura e escrita no contexto da diversidade (pp. 50-59). Mediação.

5. Cavalcanti, M. C. (2011). Bi/multilinguismo, escolarização e o (re)conhecimento de contextos minoritários, minoritarizados e invisibilizados. In M. C. Magalhães \& S. S. Fidalgo (Eds.), Questões de método e de linguagem na formação docente (pp. 171-185). Mercado de Letras.

6. Cavalcanti, M. C., \& Silva, I. R. (2007). “Já que ele não fala, podia ao menos escrever...:" o grafocentrismo naturalizado que insiste em normalizar o surdo. In A. B. Kleiman \& M. C. Cavalcanti (Eds.), Linguística aplicada: suas faces e interfaces (pp. 219-242). Mercado de Letras.

7. Erickson, F. (1989). Métodos cualitativos de investigación sobre la enseñanza. In M. C. Wittrock (Ed.), La investigación de la enseñanza II: métodos cualitativos y de observación (pp. 195-301). Paidos Ibérica.

8. Favorito, W. (2006). "O dificil são as palavras": representações de/sobre estabelecidos e outsiders na escolarização de jovens $e$ adultos surdos [Doctoral dissertation, Universidade Estadual de Campinas]. Retrieved from: https://repositorio.ufsc.br/handle/123456789/185107.

9. Fernandes, S. (2007). Avaliação em língua portuguesa para alunos surdos: algumas considerações. Secretaria de Estado da Educação do Paraná. Retrieved from: http://www.educadores.diaadia.pr.gov.br/arquivos/File/janeiro2013/o tp_artigos/sueli_fernandes.pdf.

10. Françoso, M. F. C. (2003). Família e surdez: algumas considerações aos profissionais que trabalham com famílias. In I. R. Silva, S. Kauchakje \& Z. M. Gesueli (Eds.), Cidadania, surdez e linguagem: desafios e realidades (pp. 77-88). Plexus.

11. Freeman, R. D. (1998). Bilingual education and social change. Multilingual Matters.

12. Freire, A. M. F., \& Favorito, W. (2007). Relações de poder e saber na sala de aula: contextos de interação com alunos surdos. In M. C Cavalcanti \& S. M. Bortoni-Ricardo (Eds.), Transculturalidade, linguagem e educação (pp. 207-218). Mercado de Letras.

13. Gesser, A. (2009). Libras? Que língua é essa?: crenças e preconceitos em torno da língua de sinais e da realidade surda. Parábola. 

LANGUAGE AND EDUCATION: THINKING (AND DOING) OTHERWISE

14. Gesueli, Z. M. (2003). Língua de sinais e aquisição da escrita. In I. R. Silva, S. Kauchakje \& Z. M. Gesueli (Eds.), Cidadania, surdez e linguagem: desafios e realidades (pp. 147-160). Plexus.

15. Gesueli, Z. M. (2004). A escrita como fenômeno visual nas práticas discursivas dos alunos surdos. In A. C. B. Lodi, K. M. P. Harrison \& S. R. L. Campos (Eds.), Leitura e escrita no contexto da diversidade (pp. 39-49). Mediação.

16. Giordani, L. F. (2004). Encontros e desencontros da língua escrita na educação de surdos. In A. C. B. Lodi, K. M. P. Harrison \& S. R. L. Campos (Eds.), Leitura e escrita no contexto da diversidade (pp. 7385). Mediação.

17. Giroto, C. R. M., Toppan Junior, N., Martins, S. E. O. S. \& Veri, D. R. (2005). Programa de atendimento bilíngue a surdos, familiares e professores: um enfoque interdisciplinar. In Anais da IV Jornada do Núcleo de Ensino de Marília. Universidade Estadual Paulista.

18. Góes, M. C. R., \& Tartuci D. (2002). Alunos surdos na escola regular: as experiências de letramento e os rituais da sala de aula. In A C. B. Lodi, K. M. P. Harrison, S. R. L. Campos \& O. Teske (Eds.), Letramento e minorias (pp. 110-119). Mediação.

19. Goldfeld, M. (2006). Atendimento fonoaudiológico para surdos com enfoque bilíngue e interacionista. In S. Frota \& M. Goldfeld (Eds.), Enfoques em audiologia e surdez (pp. 282-320). AM3 Artes.

20. Hamel, R. E. (2003). Direitos linguísticos como direitos humanos: debates e perspectivas. In G. M. Oliveira (Ed.), Declaração universal dos direitos linguísticos: novas perspectivas em política linguística (pp. 47-80). Mercado de Letras.

21. Hornberger, N. H. (2001). Criando contextos eficazes de aprendizagem para o letramento bilíngue. In M. I. P. Cox \& A. A. Assis-Peterson (Eds.), Cenas de sala de aula (pp. 23-50). Mercado de Letras.

22. Karnopp, L. B., \& Pereira, M. C. C. (2004). Concepções de leitura e escrita e educação de surdos. In A. C. B. Lodi, K. M. P. Harrison \& S. R. L. Campos (Eds.), Leitura e escrita no contexto da diversidade (pp. 33-38). Mediação.

23. Kumada, K. M. O. (2012). "No começo ele não tem língua nenhuma, ele não fala, ele não tem Libras, né?": representações sobre línguas de sinais caseiras [Master's thesis, Universidade Estadual de Campinas]. http://repositorio.unicamp.br/jspui/handle/REPOSIP/269529

24. Law n. 7.853 (1989, Oct. 24) (Brazil). Dispõe sobre o apoio às pessoas portadoras de deficiência, sua integração social, sobre a Coordenadoria 
Nacional para Integração da Pessoa Portadora de Deficiência - Corde, institui a tutela jurisdicional de interesses coletivos ou difusos dessas pessoas, disciplina a atuação do Ministério Público, define crimes, e dá outras providências. http://www.planalto.gov.br/ccivil_03/leis/17853.htm.

25. Lopes, M. C. (2006). O direito de aprender na escola de surdos. In A. S. Thomas \& M. C. Lopes (Eds.), A invenção da surdez II: espaços e tempos de aprendizagem na educação de surdos (pp. 26-46). EDUNISC.

26. Maher, T. M. (2007). A educação do entorno para interculturalidade e o plurilinguismo. In A. B. Kleiman \& M. C. Cavalcanti (Eds.), Linguística aplicada: suas faces e interfaces (pp. 255-270). Mercado de Letras.

27. Mendes, E. G. (2006). A radicalização do debate sobre inclusão escolar no Brasil. Revista Brasileira de Educação, 11(33), 387-405.

28. Quadros, R. M., \& Karnopp L. B. (2004). Língua de sinais brasileira: estudos linguísticos. Artmed.

29. Sacks, O. (1998). Vendo vozes: uma viagem ao mundo dos surdos. Companhia das Letras.

30. Severino, A. J. (2007). Metodologia do trabalho científico (23th ed.). Cortez.

31. Silva, A. B. P. (2003). Surdez, inteligência e afetividade. In I. R. Silva, S. Kauchakje \& Z. M. Gesueli (Eds.), Cidadania, surdez e linguagem: desafios e realidades (pp. 89-97). Plexus.

32. Silva, I. R. (2005). As representações do surdo na escola e na família: entre a (in)visibilização da diferença e da "deficiência" [Doctoral dissertation, Universidade Estadual de Campinas]. http://repositorio.unicamp.br/handle/REPOSIP/269552.

33. Silva, I. R., Kauchakje, S., \& Gesueli, Z. M. (Eds.). (2003). Cidadania, surdez e linguagem: desafios e realidades. Plexus.

34. Silva, I. R. (2003). Considerações sobre a construção da narrativa pelo aluno surdo. In I. R. Silva, S. Kauchakje \& Z. M. Gesueli (Eds.), Cidadania, surdez e linguagem: desafios e realidades (pp. 115-146). Plexus.

35. Skliar, C. (1998). Estudos surdos em educação: problematizando a normalidade. In C. Skliar (Ed.), A surdez: um olhar sobre as diferenças (pp. 7-32). Mediação.

36. Skliar, C., \& Quadros, R. (2000). Invertendo epistemologicamente o problema da inclusão: os ouvintes no mundo dos surdos. Estilos da Clínica, 5(9), 32-51. 
37. Skutnabb-Kangas, T. (1981). Bilingualism or not: the education of minorities. Multilingual Matter.

38. Tervoort, B. T. (1961). Esoteric symbolism in the communication behavior of young deaf children. American Annals of the Deaf, 106(5), 436-480.

39. Turato, E. R. (2013). Tratado da metodologia da pesquisa clínicoqualitativa: construção teórico-epistemológica, discussão comparada e aplicação nas áreas da saúde e humanas (6th ed.). Vozes.

40. United Nations (1948). Universal declaration of human rights. https://www.ohchr.org/EN/UDHR/Pages/Language.aspx?LangID=po r.

41. Vilhalva, S. (2009). Mapeamento das línguas de sinais emergentes: um estudo sobre as comunidades linguísticas indígenas de Mato Grosso do Sul [Master's thesis, Universidade Federal de Santa Catarina]. https://repositorio.ufsc.br/handle/123456789/92972. 